\title{
Alkali element background reduction in laser ICP-MS
}

\author{
C. W. Magee Jr. ${ }^{1,2}$ and C. A. Norris ${ }^{1,3}$ \\ ${ }^{1}$ Research School of Earth Sciences, Australian National University, Canberra ACT 2600, Australia \\ ${ }^{2}$ Australian Scientific Instruments, 111-113 Gladstone St. Fyshwick ACT 2609, Australia \\ ${ }^{3}$ Department of Earth Sciences, University of Oxford, Oxford, OX13AN, UK
}

Correspondence to: C. W. Magee Jr. (charles.magee@ asi-pl.com.au)

Received: 16 September 2014 - Published in Geosci. Instrum. Method. Data Syst. Discuss.: 17 November 2014

Revised: 3 March 2015 - Accepted: 3 March 2015 - Published: 17 March 2015

\begin{abstract}
Alkali backgrounds in laser ablation ICP-MS analyses can be enhanced by electron-induced ionisation of alkali contamination on the skimmer cone, reducing effective detection limits for these elements. Traditionally, this problem is addressed by isolating analyses of high-alkali materials onto a designated cone set, or by operating the ICPMS in a "soft extraction" mode, which reduces the energy of electrons repelled into the potentially contaminated sampling cone by the extraction field. Here we present a novel approach, where we replace the traditional alkali glass tuning standards with synthetic low-alkali glass reference materials. Using this vitreous tuning solution, we find that this approach reduces the amount of alkali contamination produced, halving backgrounds for the heavy alkali elements without any change to analytical procedures. Using segregated cones is still the most effective method for reducing lithium backgrounds, but since the procedures are complimentary, both can easily be applied to the routine operations of an analytical lab.
\end{abstract}

\section{Introduction}

In solution ICP-MS, tuning and calibration are performed using carefully selected, high-purity aqueous solutions. In contrast, laser ablation ICP-MS (LA-ICP-MS) tuning and calibration are often conducted using natural or multielement glass reference materials such as the NIST 600series glasses, which are generally not specifically chosen or synthesised for the purpose of tuning a plasma source mass spectrometer. This can create a host of contamination issues (Eggins and Shelley, 2002).
The LA-ICP-MS Agilent 7500 lab in operation at the Research School of Earth Sciences (RSES), Australian National University (ANU), during 2006, was a general-purpose, multidisciplinary analytical facility. Samples analysed included zircon and other minerals for U-Pb geochronology; geological, synthetic, and biogenic carbonates for paleoclimatology; mantle minerals for diamond indicator studies; igneous, metamorphic, and synthetic minerals and silicate melts for the study of petrogenesis of various mantle and crustal rocks at a variety of pressures and temperatures; synthetic and natural sulfides for thermodynamic or ore-genesis research, and occasional solution (no laser ablation) ICP-MS analyses of platinum group elements. The extensive variety of analytical procedures performed led to a number of potential contamination and cross-contamination issues.

Of particular concern were the alkali elements. Once alkali elements are introduced to the skimmer and sampler cones, electron-induced secondary ionisation can create large sample-independent backgrounds. Analytical protocols such as the soft extraction technique (Tye and Sakata, 2000) will reduce these backgrounds, but at the expense of overall sensitivity, especially for low-mass ions.

Two experiments were performed in the LA- ICP-MS Agilent $7500 \mathrm{lab}$, in order to determine the ease and effectiveness of reducing alkali loads and backgrounds without changing analytical procedures. The first method involved segregating cones into high, low, and average expected alkali concentrations. This is standard procedure in many labs, and served as a baseline for effectiveness, to which we could compare our new procedure. The second experiment replaced the NIST612 standard with a custom-built alkali-free glass (Tune-1) with a composition especially chosen for tuning and evaluation of laser ablation and ICP-MS performance. 
This was, in effect, the vitreous equivalent of a tuning solution, with the tuning elements dissolved into a glass instead of dilute nitric acid. While this may seem to be an obvious approach, we do not know of any previous attempts to dissolve tuning species into a glass with a composition chosen to eliminate unwanted contaminants.

\section{Methods}

Cone segregation involved analysing samples with different expected alkali contents on different cones. A "dirty" cone set (C-5) was assigned to use for lithium borates (Eggins, 2003), stoichiometric sodium and potassium minerals, and doped or felsic glasses. Another cone set (E-1) was set aside for low-level lithium, rubidium, and caesium work. The remaining cones were used for routine mineral analyses that did not fall into either of these two categories. The backgrounds of $\mathrm{Li}, \mathrm{Na}, \mathrm{Rb}$, and $\mathrm{Cs}$ for the various cone sets were monitored during the daily tune-up from March to July 2006. Potassium was not recorded, as the backgrounds of both stable $\mathrm{K}$ isotopes are complicated by argon hydrides and the shoulder of the intense ${ }^{40} \mathrm{Ar}^{+}$peak from the argon plasma. ${ }^{40} \mathrm{~K}^{+}$was completely obscured by ${ }^{40} \mathrm{Ar}^{+}$.

Tuning the instrument in the morning before the analysis can comprise $5-25 \%$ of the total daily plasma load, depending on the duration (2-12 h) and type of analyses performed. The concentrations of $\mathrm{Li}, \mathrm{Na}$, and $\mathrm{Rb}$ in NIST 612 and 610 are significantly higher than MORB (Sun and McDonough, 1989), while the Cs concentration in these synthetic glasses is many times higher than most natural samples (Table 1). A nominally alkali-free glass (Tune-1) was synthesised to replace the NIST 612 glass previously used in tuning. Tune-1 was used from August to December 2006, and backgrounds and machine performance were recorded in a similar fashion.

Tune-1 was designed to be an anorthite-wollastonitediopside-quartz eutectic CMAS glass (Longhi, 1987). This composition was chosen for the low melting point $\left(1129^{\circ} \mathrm{C}\right)$ and low silica content, which allows for more rapid diffusive homogenisation of the dopants. The dopants were chosen according to the following criteria: (1) the element must be soluble in the glass. (2) The element must be refractory enough not to evaporate during fusion in the one atmosphere furnace. (3) To minimise interferences, elements with few isotopes were favoured over those with many. (4) A decent mass range was desired, with a dopant every 40 to $50 \mathrm{AMU}$. (5) Rare earth elements were avoided, as it was unclear how well separated the available reagents were. (6) An element with an isotopic ratio greater than 10:1 but less than 20:1 was desired for performing deadtime corrections to the electron multiplier $\left({ }^{138} \mathrm{Ba} /{ }^{135} \mathrm{Ba} \sim 11\right.$ was eventually chosen). (7) If possible, elements which ionised well in the ICP were selected. (8) The element had to be available on the shelf of the experimental petrology store, as this project was un- funded. (9) $\mathrm{U}$ and Th were both included, as their relative behaviour was of interest to geochronologists at the time.

To satisfy these requirements as best as possible, Tune- 1 was doped with 50 micromols mol $^{-1}$ of $\mathrm{Be}, \mathrm{Mn}, \mathrm{Nb}, \mathrm{Ba}, \mathrm{Ta}$, $\mathrm{Th}$, and $\mathrm{U}$. The glass was synthesised via the silica gel process (Hamilton and Henderson, 1968), with the $\mathrm{Ca}, \mathrm{Mg}, \mathrm{Al}$, $\mathrm{Be}, \mathrm{Mn}, \mathrm{Ba}, \mathrm{Th}$, and $\mathrm{U}$ dissolved as nitrates, and the $\mathrm{Nb}, \mathrm{Ta}$, and $\mathrm{Si}$ added as ethoxides. The Tune-1 measured composition is given in Table 2 .

The major element $(\mathrm{Ca}, \mathrm{Si}, \mathrm{Al}, \mathrm{Mg})$ composition of the glass was determined using WD spectrometry on the Cameca SX100 electron microprobe at RSES. The beam conditions were $15 \mathrm{kV}$ and $10 \mathrm{nA}$, with the spot purposefully defocused to $5 \mu \mathrm{m}$. The following synthetic standards were used for calibration: $\mathrm{Ca}$ and $\mathrm{Si}$, wollastonite/ $\mathrm{CaSiO}_{3}, \mathrm{Al}, \mathrm{CaAl}_{2} \mathrm{O}_{4}, \mathrm{Mg}$, and periclase $/ \mathrm{MgO}$. All standards were prepared at RSES from high-purity powders (B. Hibberson, personal communication, 2006) and appropriate conditions of synthesis. Forty points across the sample were analysed and the results statistically collated to give the standard deviation reported.

The trace elemental composition of the glass was determined using laser ICP-MS. LA-ICP-MS analysis was performed at RSES using the Agilent 7500 series mass spectrometer. The Lambda Physik lpx 120i 193nm excimer laser laser supplied by Resonetics was attenuated by using a $25 \%$ reflectance mirror on the final bend of the custom-built laser flight tube, yielding a power output of approximately 2$3 \mathrm{~J} \mathrm{~cm}^{-2}$. The custom-built two-volume mixing cell is the predecessor to both the Laurin Technic RESOlution cell and the Helix cells sold commercially, with the details described in Eggins et al. (2003), and references therein. Ablation took place at $5 \mathrm{~Hz}$.

The following analytical technique was used to determine the $\mathrm{Rb}$ and $\mathrm{Cs}$ content of Tune-1. Selected chalcophile elements were also measured for a different experiment, and those results are not reported here. Analysis time was $75 \mathrm{~s}$, with $25 \mathrm{~s}$ of background collected before ablation commenced. A 187 micron spot was used. The following masses were measured: ${ }^{9} \mathrm{Be},{ }^{29} \mathrm{Si},{ }^{43} \mathrm{Ca},{ }^{85} \mathrm{Rb},{ }^{107} \mathrm{Ag},{ }^{109} \mathrm{Ag},{ }^{111} \mathrm{Cd}$, ${ }^{114} \mathrm{Cd},{ }^{118} \mathrm{Sn},{ }^{119} \mathrm{Sn},{ }^{121} \mathrm{Sb},{ }^{123} \mathrm{Sb},{ }^{133} \mathrm{Cs},{ }^{182} \mathrm{~W},{ }^{183} \mathrm{~W},{ }^{203} \mathrm{Tl}$, ${ }^{205} \mathrm{Tl},{ }^{208} \mathrm{~Pb}^{209} \mathrm{Bi},{ }^{232} \mathrm{Th},{ }^{238} \mathrm{U}$. All isotopes were counted for $30 \mathrm{~ms}$ except for $\mathrm{Si}$ and $\mathrm{Ca}$, which were measured for $5 \mathrm{~ms}$. Including switching time, this cycle was repeated every $0.6222 \mathrm{~s}$.

For the dopants, $\mathrm{Na}$, and $\mathrm{Li}$, a 54 um spot was used, with a laser rep rate of $4 \mathrm{~Hz}$. Analysis time was $60 \mathrm{~s}$, with $20 \mathrm{~s}$ of background collected before ablation commenced. The following masses were measured: ${ }^{7} \mathrm{Li},{ }^{9} \mathrm{Be},{ }^{23} \mathrm{Na},{ }^{25} \mathrm{Mg},{ }^{27} \mathrm{Al}$, ${ }^{29} \mathrm{Si},{ }^{31} \mathrm{P},{ }^{43} \mathrm{Ca},{ }^{47} \mathrm{Ti},{ }^{55} \mathrm{Mn},{ }^{57} \mathrm{Fe},{ }^{93} \mathrm{Nb},{ }^{137} \mathrm{Ba},{ }^{181} \mathrm{Ta},{ }^{232} \mathrm{Th}$, ${ }^{238} \mathrm{U}$. All isotopes were counted for $30 \mathrm{~ms}$ except for $\mathrm{Na}, \mathrm{Mg}$, $\mathrm{Ca}$ and $\mathrm{Fe}$, which were measured for $20 \mathrm{~ms}$, and $\mathrm{Si}$, which was measured for $10 \mathrm{~ms}$.

Data were reduced via Excel spreadsheet in the manner of Longerich et al. (1996). ${ }^{43} \mathrm{Ca}$ was the internal standard, using the EPMA value of $28.46 \% \mathrm{CaO}$. Trace element abundances 
Table 1. Alkali contents of popular natural and synthetic ICPMS reference materials. Li, Rb, Cs in ppm $\left(\mu g \mathrm{~g}^{-1}\right)$. Na is weight percent oxide. Values from Govindaraju (1994), Eggins et al. (1997), Norman et al. (1998), Hinton (1999), and Gao et al. (2002). LiBO flux Li content is an estimate; exact content depends on tetraborate / metaborate ratio, and rock type fluxed.

\begin{tabular}{llrrrrrr}
\hline Element & LiBO flux & 610 & 612 & BCR & BHVO & Tune-1 & Units \\
\hline $\mathrm{Li}$ & $\approx 83000$ & 484 & 41 & 9.6 & 4.9 & 0.184 & $\mu \mathrm{g} \mathrm{g}^{-1}$ \\
$\mathrm{Na}_{2} \mathrm{O}$ & variable & $13.76 \%$ & $14 \%$ & $3.15 \%$ & $2.26 \%$ & $0.0021 \%$ & $\% \mathrm{~g} \mathrm{~g}^{-1}$ \\
$\mathrm{Rb}$ & variable & 431 & 32 & 49 & 9.5 & 0.012 & $\mu \mathrm{g} \mathrm{g}^{-1}$ \\
$\mathrm{Cs}$ & variable & 360 & 41 & 1.1 & 0.1 & 0.01 & $\mu \mathrm{g} \mathrm{g}^{-1}$ \\
\hline
\end{tabular}

Table 2. Major and trace elemental composition of glass Tune-1. Errors are $1 \sigma$. Major elements from EPMA, minor elements from ICPMS.

\begin{tabular}{|c|c|c|}
\hline Element & \multicolumn{2}{|c|}{$\% \mathrm{gg}^{-1}$} \\
\hline $\mathrm{CaO}$ & \multicolumn{2}{|c|}{$28.5 \% \pm 0.1 \%$} \\
\hline $\mathrm{MgO}$ & \multicolumn{2}{|c|}{$2.16 \% \pm 0.04 \%$} \\
\hline $\mathrm{Al}_{2} \mathrm{O}_{3}$ & \multicolumn{2}{|c|}{$13.1 \% \pm 0.1 \%$} \\
\hline $\mathrm{SiO}_{2}$ & \multicolumn{2}{|c|}{$56.5 \% \pm 0.2 \%$} \\
\hline Dopant & $\mu \mathrm{g} \mathrm{g}^{-1}$ & $\mu \mathrm{mol} \mathrm{mol}-1$ \\
\hline $\mathrm{Be}$ & $42.1 \pm 0.2$ & $80.1 \pm 0.3$ \\
\hline $\mathrm{Mn}$ & $186.3 \pm 0.9$ & $58.1 \pm 0.3$ \\
\hline $\mathrm{Nb}$ & $314.1 \pm 0.8$ & $57.9 \pm 0.2$ \\
\hline $\mathrm{Ba}$ & $429.9 \pm 1.2$ & $53.7 \pm 0.1$ \\
\hline $\mathrm{Ta}$ & $612.8 \pm 2.7$ & $58.0 \pm 0.3$ \\
\hline Th & $704.1 \pm 2.5$ & $52.0 \pm 0.2$ \\
\hline $\mathrm{U}$ & $723.7 \pm 14.6$ & $52.1 \pm 1.0$ \\
\hline Contaminant & $\mu \mathrm{gg}^{-1}$ & $\mu \mathrm{mol} \mathrm{mol}-1$ \\
\hline $\mathrm{Li}$ & $0.17 \pm 0.02$ & $0.43 \pm 0.04$ \\
\hline $\mathrm{Na}$ & $14.8 \pm 1.3$ & $11.0 \pm 0.9$ \\
\hline $\mathrm{Rb}$ & $0.012 \pm 0.002$ & $0.0025 \pm 0.0004$ \\
\hline Cs & $0.010 \pm 0.001$ & $0.0013 \pm 0.0001$ \\
\hline
\end{tabular}

were standardised using the Pearce et al. (1997) values for NIST 612. The concentrations of dopants and alkali contaminants are listed in Table 2.

Each morning, following the daily instrumental tuning regime, alkali backgrounds were recorded as raw counts, and

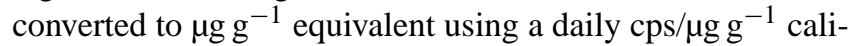
bration factor. The counts per $\mu \mathrm{g} \mathrm{g}^{-1}$ in routine analysis can vary by a factor of 2 due to the condition of the cones, the laser and optics, the electrostatic lenses, and other unknown factors. This is why a $\mu \mathrm{g} \mathrm{g}^{-1}$ equivalent is reported instead of raw counts.

Once Tune-1 was in use, freshly cleaned cones were installed on those days when low-level analyses of alkali elements were to be performed. This subset of the tune glass backgrounds is representative of the backgrounds that were present during alkali analysis. Low-level alkali analyses were generally standardised against natural basalt BCR-2G, which
Table 3. Mean daily backgrounds in ppm equivalent. Low conc refers to cone set E-5, which was reserved for low-alkali samples. Li free refers to all cones except the dedicated high-alkali set. Clean cones is the background on freshly cleaned cones after tuning on the Tune-1 glass, before any analyses are performed.

\begin{tabular}{lrrrrr}
\hline Cones & Standard & $\mathrm{Li}$ & $\mathrm{Na}$ & $\mathrm{Rb}$ & $\mathrm{Cs}$ \\
\hline All & NIST 612 & 86.6 & 623 & 0.090 & 0.037 \\
Li free & NIST 612 & 4.20 & 642 & 0.094 & 0.039 \\
Low conc & NIST 612 & 0.29 & 705 & 0.090 & 0.020 \\
Li free & Tune-1 & 1.83 & 474 & 0.044 & 0.015 \\
Low conc & Tune-1 & 0.37 & 499 & 0.054 & 0.016 \\
Fresh cones & Tune-1 & 0.54 & 161 & 0.022 & 0.005 \\
\hline
\end{tabular}

has lower alkali concentrations than NIST 612 or 610 (Table 1).

\section{Results}

The cone segregation experiment, using NIST 612 as a tuning glass, was performed from March to July 2006. In early August, the custom-made Tune-1 glass replaced NIST 612 as the glass used for tuning. Cone segregation of the highalkali cone set (C-5) was continued, and data were collected through December 2006.

The mean $\mu \mathrm{gg}^{-1}$ equivalent backgrounds for $\mathrm{Li}, \mathrm{Na}, \mathrm{Rb}$, and $\mathrm{Cs}$ are reported in Table 3 , and the daily values are in Table 4 . The high-alkali cone set (C-5) has significantly higher backgrounds for $\mathrm{Li}$ than all other cone sets, but the low-alkali cone set (E-1) is similar to the other cones (sample cones D, J, A, K; skimmer cones 6, 2, 4, 9, 7) for all elements except lithium. Cone segregation was quite effective at reducing $\mathrm{Li}$ backgrounds on the low Li cone set (Fig. 1, Table 3). The use of low-concentration cones dropped the Cs background by a factor of about 2. However, cone segregation had no appreciable impact on $\mathrm{Na}$ or $\mathrm{Rb}$ background levels.

The adoption of Tune-1 approximately halved the backgrounds for $\mathrm{Li}, \mathrm{Rb}$, and $\mathrm{Cs}$ compared to the backgrounds associated with tuning on NIST 612 . Na was reduced by $25 \%$. However, the background produced by a newly cleaned set of cones (tuned using Tune-1) is 2-3 times lower still (Fig. 1, 

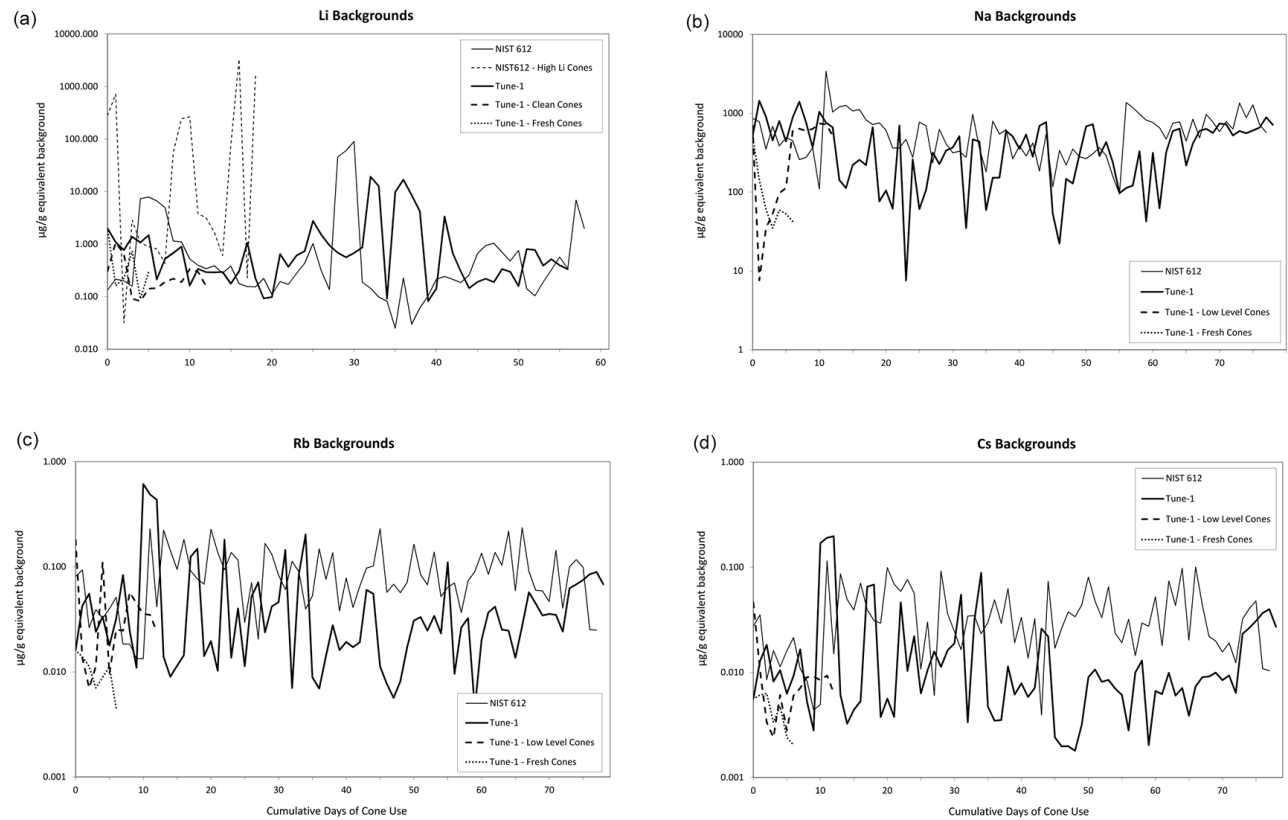

Figure 1. (a) Daily Li backgrounds as $\mu \mathrm{g} \mathrm{g}{ }^{-1}$ equivalent for high Li cones, standard cones tuned with NIST612, standard cones tuned with Tune-1, low-level cones tuned with Tune-1, and freshly cleaned cones tuned with Tune-1. (b) Daily Na backgrounds as $\mu g g^{-1}$ equivalent for tuning done with NIST 612, Tune-1, and Tune-1 with low-level and freshly cleaned sets of cones for low-level alkali work. (c) Daily Rb backgrounds as $\mu \mathrm{g} \mathrm{g}^{-1}$ equivalent for tuning done with NIST 612, Tune-1, and Tune-1 with low-level and freshly cleaned sets of cones for low-level alkali work. (d) Daily Cs backgrounds as $\mu \mathrm{g} \mathrm{g}^{-1}$ equivalent for tuning done with NIST 612, Tune-1, and Tune-1 with low-level and freshly cleaned sets of cones for low-level alkali work.

Table 3), showing that backgrounds can be dropped for those days when low-level alkali elements are to be analysed.

\section{Discussion}

The analysis of the tune glass reveals a few errors in synthesis. Excess Be is caused by an aborted attempt to dissolve Be metal in concentrated nitric acid before adding Be as a nitrate solution. The Si deficit is probably a result of incomplete hydration of the tetra ethyl orthosilicate, and explains the slightly high trace elemental compositions. The glass appears to be homogenous despite these minor problems. The alkali content, while detectable, is orders of magnitude lower than the NIST 612 glass.

Day-to-day background levels in alkali elements were highly variable throughout the study. Two instances where a lithium borate was run on a cone set other than the designated one are clearly visible in the data (Fig. 1a). Many, but not all, of the other variations can be explained by use of NIST 612 or 610 as a reference material under various spot sizes and ablation times. Cleaning cones generally dropped the backgrounds of all elements except lithium. However, despite the day-to-day noise, some systematic trends were noticed.

Segregating lithium borate flux experiments onto a dedicated cone set produced an order of magnitude decrease in $\mathrm{Li}$ backgrounds for non-Li cones, as expected. Replacing the
NIST glass used for tuning with a custom-made glass reduced most alkali backgrounds by about a factor of 2 . The changes only involved machine set-up, tuning and performance verification, and did not require any changes to methods or standardisation for analysing unknowns. Judging by the alkali levels found on clean cones, a further factor of 2-3 reduction is possible for days when alkali need to be measured at the lowest levels. We note, however, that the lithium backgrounds are lowest for the low-alkali cones tuning with NIST 612. The reason these are higher when the tune glass is used is not clear, but it is possible that the spike in Li backgrounds on the low-level cones at the end of the NIST run was a contamination event that was never properly cleaned, and that persisted into the Tune-1 experiments.

\section{Conclusions}

When tuning LA-ICP-MS we have observed that use of the low-alkali glass, Tune-1, is an effective means of reducing alkali backgrounds and improving analytical precision and lowering limits of detection. For the heavy alkali in particular, it is more effective than simply segregating cones based on expected target composition.

This reduction in alkali contamination does not preclude use of instrumental methods such as soft extraction (Tye and Sakata, 2000) to further depress the alkali background. 
Table 4a. Mean daily backgrounds in $\mu \mathrm{g} \mathrm{g}^{-1}$ equivalent from tuning using the NIST 612 glass.

\begin{tabular}{|c|c|c|c|c|c|c|}
\hline Date & $\begin{array}{r}\text { Skimmer } \\
\text { cone }\end{array}$ & $\begin{array}{r}\text { Sampler } \\
\text { cone }\end{array}$ & $\mathrm{Li} \mathrm{Bkg}$ & $\mathrm{Na} \mathrm{Bkg}$ & $\mathrm{Rb}$ Bkg & Cs Bkg \\
\hline 10 Mar 2006 & $\mathrm{j}$ & 2 & 0.13 & 860.74 & 0.081 & 0.028 \\
\hline 13 Mar 2006 & $\mathrm{j}$ & 2 & 0.22 & 783.27 & 0.093 & 0.035 \\
\hline 14 Mar 2006 & $j$ & 2 & 0.20 & 350.45 & 0.026 & 0.009 \\
\hline 15 Mar 2006 & $\mathrm{j}$ & 2 & 0.16 & 683.83 & 0.039 & 0.016 \\
\hline 16 Mar 2006 & $\mathrm{j}$ & 2 & 7.31 & 384.08 & 0.032 & 0.011 \\
\hline 17 Mar 2006 & $\mathrm{j}$ & 2 & 7.85 & 490.26 & 0.040 & 0.016 \\
\hline $21 \mathrm{Mar} 2006$ & $j$ & 2 & 6.63 & 449.75 & 0.051 & 0.021 \\
\hline 22 Mar 2006 & $\mathrm{c}$ & 5 & 280.58 & 258.70 & 0.018 & 0.011 \\
\hline 23 Mar 2006 & $\mathrm{c}$ & 5 & 712.95 & 275.27 & 0.018 & 0.008 \\
\hline 24 Mar 2006 & $\mathrm{j}$ & 2 & 4.97 & 363.73 & 0.013 & 0.004 \\
\hline 27 Mar 2006 & $\mathrm{j}$ & 2 & 1.14 & 109.62 & 0.013 & 0.005 \\
\hline 29 Mar 2006 & $\mathrm{k}$ & 4 & 1.10 & 3425.75 & 0.230 & 0.115 \\
\hline 31 Mar 2006 & $\mathrm{k}$ & 4 & 0.52 & 1037.87 & 0.042 & 0.015 \\
\hline 3 Apr 2006 & $\mathrm{k}$ & 4 & 0.40 & 1208.37 & 0.223 & 0.087 \\
\hline 4 Apr 2006 & $\mathrm{k}$ & 4 & 0.34 & 1261.59 & 0.143 & 0.049 \\
\hline 5 Apr 2006 & $\mathrm{k}$ & 4 & 0.39 & 1068.95 & 0.095 & 0.039 \\
\hline 6 Apr 2006 & $\mathrm{k}$ & 4 & 0.28 & 1119.94 & 0.182 & 0.071 \\
\hline 7 Apr 2006 & d & 9 & 0.38 & 824.22 & 0.092 & 0.039 \\
\hline 10 Apr 2006 & d & 9 & 0.18 & 721.55 & 0.077 & 0.031 \\
\hline 11 Apr 2006 & d & 9 & 0.16 & 756.37 & 0.068 & 0.029 \\
\hline $13 \mathrm{Apr} 2006$ & & & 0.15 & 608.52 & 0.228 & 0.100 \\
\hline $18 \mathrm{Apr} 2006$ & & & 0.22 & 363.35 & 0.138 & 0.069 \\
\hline 19 Apr 2006 & & & 0.11 & 362.53 & 0.094 & 0.059 \\
\hline 20 Apr 2006 & & & 0.19 & 469.20 & 0.137 & 0.077 \\
\hline $21 \mathrm{Apr} 2006$ & & & 0.17 & 275.83 & 0.116 & 0.057 \\
\hline 26 Apr 2006 & $\mathrm{e}$ & 1 & 0.28 & 772.24 & 0.029 & 0.011 \\
\hline 27 Apr 2006 & & & 0.43 & 695.87 & 0.071 & 0.030 \\
\hline 1 May 2006 & $\mathrm{c}$ & 5 & 0.03 & 234.94 & 0.020 & 0.006 \\
\hline 2 May 2006 & $\mathrm{c}$ & 5 & 2.85 & 625.57 & 0.167 & 0.092 \\
\hline 3 May 2006 & $\mathrm{c}$ & 5 & 1.06 & 409.54 & 0.131 & 0.036 \\
\hline 4 May 2006 & c & 5 & 0.89 & 315.58 & 0.083 & 0.025 \\
\hline 5 May 2006 & $\mathrm{c}$ & 5 & 0.81 & 330.10 & 0.061 & 0.016 \\
\hline 8 May 2006 & $\mathrm{c}$ & 5 & 0.43 & 276.55 & 0.113 & 0.034 \\
\hline 9 May 2006 & $j$ & 2 & 1.03 & 972.29 & 0.090 & 0.035 \\
\hline 10 May 2006 & & & 0.31 & 361.38 & 0.040 & 0.023 \\
\hline 11 May 2006 & & & 0.14 & 180.90 & 0.053 & 0.030 \\
\hline 15 May 2006 & & & 45.66 & 797.04 & 0.148 & 0.049 \\
\hline 16 May 2006 & & & 59.58 & 542.41 & 0.076 & 0.029 \\
\hline 17 May 2006 & & & 89.88 & 620.02 & 0.136 & 0.063 \\
\hline 19 May 2006 & & & 0.19 & 263.64 & 0.038 & 0.019 \\
\hline 22 May 2006 & & & 0.14 & 386.39 & 0.078 & 0.033 \\
\hline 23 May 2006 & & & 0.10 & 287.61 & 0.041 & 0.014 \\
\hline 24 May 2006 & & & 0.08 & 420.53 & 0.065 & 0.033 \\
\hline 29 May 2006 & $\mathrm{e}$ & 1 & 0.03 & 185.05 & 0.097 & 0.004 \\
\hline 31 May 2006 & $j$ & 2 & 0.23 & 540.93 & 0.102 & 0.074 \\
\hline 1 Jun 2006 & $\mathrm{e}$ & 1 & 0.03 & 117.14 & 0.231 & 0.017 \\
\hline 1 Jun 2006 & $\mathrm{j}$ & 2 & 0.06 & 338.97 & 0.057 & 0.026 \\
\hline 5 Jun 2006 & & & 0.10 & 219.85 & 0.068 & 0.038 \\
\hline 6 Jun 2006 & & & 0.21 & 352.27 & 0.057 & 0.034 \\
\hline 7 Jun 2006 & & & 0.24 & 281.16 & 0.071 & 0.044 \\
\hline 8 Jun 2006 & & & 0.21 & 266.03 & 0.164 & 0.081 \\
\hline 9 Jun 2006 & & & 0.19 & 306.67 & 0.084 & 0.047 \\
\hline 13 Jun 2006 & $\mathrm{j}$ & 2 & 0.26 & 366.77 & 0.067 & 0.033 \\
\hline 14 Jun 2006 & $\mathrm{c}$ & 5 & 54.31 & 290.85 & 0.138 & 0.065 \\
\hline 15 Jun 2006 & c & 5 & 245.09 & 158.64 & 0.052 & 0.023 \\
\hline 16 Jun 2006 & $\mathrm{c}$ & 5 & 263.34 & 94.82 & 0.064 & 0.019 \\
\hline 19 Jun 2006 & $\mathrm{c}$ & 5 & 3.80 & 1369.72 & 0.070 & 0.032 \\
\hline 21 Jun 2006 & $\mathrm{c}$ & 5 & 3.16 & 1182.13 & 0.037 & 0.014 \\
\hline 22 Jun 2006 & $\mathrm{c}$ & 5 & 1.68 & 977.39 & 0.073 & 0.030 \\
\hline 23 Jun 2006 & $\mathrm{c}$ & 5 & 0.61 & 819.26 & 0.090 & 0.027 \\
\hline 26 Jun 2006 & $\mathrm{c}$ & 5 & 76.51 & 764.24 & 0.135 & 0.052 \\
\hline 27 Jun 2006 & $\mathrm{c}$ & 5 & 3279.83 & 657.11 & 0.085 & 0.018 \\
\hline 28 Jun 2006 & $\mathrm{j}$ & 2 & 0.66 & 470.63 & 0.137 & 0.074 \\
\hline 4 Jul 2006 & d & 4 & 0.94 & 748.62 & 0.104 & 0.043 \\
\hline $5 \mathrm{Jul} 2006$ & d & 4 & 1.04 & 780.64 & 0.219 & 0.098 \\
\hline 6 Jul 2006 & $\mathrm{c}$ & 5 & 0.23 & 443.88 & 0.059 & 0.020 \\
\hline 7 Jul 2006 & d & 4 & 0.70 & 843.98 & 0.236 & 0.101 \\
\hline $12 \mathrm{Jul} 2006$ & d & 4 & 0.48 & 486.56 & 0.091 & 0.044 \\
\hline $13 \mathrm{Jul} 2006$ & $\mathrm{e}$ & 1 & 0.76 & 971.26 & 0.060 & 0.022 \\
\hline $14 \mathrm{Jul} 2006$ & $\mathrm{e}$ & 1 & 0.14 & 774.74 & 0.059 & 0.020 \\
\hline $18 \mathrm{Jul} 2006$ & $\mathrm{e}$ & 1 & 0.10 & 585.21 & 0.047 & 0.016 \\
\hline $20 \mathrm{Jul} 2006$ & $\mathrm{e}$ & 1 & 0.19 & 787.62 & 0.144 & 0.019 \\
\hline $21 \mathrm{Jul} 2006$ & $\mathrm{e}$ & 1 & 0.32 & 630.06 & 0.040 & 0.012 \\
\hline $25 \mathrm{Jul} 2006$ & $\mathrm{e}$ & 1 & 0.57 & 1354.36 & 0.100 & 0.032 \\
\hline 27 Jul 2006 & $\mathrm{e}$ & 1 & 0.34 & 878.88 & 0.117 & 0.040 \\
\hline 3 Aug 2006 & $\mathrm{c}$ & 5 & 1575.30 & 1280.07 & 0.099 & 0.048 \\
\hline 4 Aug 2006 & a & 4 & 6.87 & 723.24 & 0.025 & 0.011 \\
\hline 7 Aug 2006 & a & 4 & 1.99 & 567.16 & 0.025 & 0.010 \\
\hline
\end{tabular}

Table 4b. Mean daily backgrounds in $\mu \mathrm{g} \mathrm{g}^{-1}$ equivalent from tuning using the Tune-1 glass.

\begin{tabular}{|c|c|c|c|c|c|c|}
\hline Date & $\begin{array}{l}\text { Skimmer } \\
\text { cone }\end{array}$ & $\begin{array}{r}\text { Sampler } \\
\text { cone }\end{array}$ & $\mathrm{Li} \mathrm{Bkg}$ & Na Bkg & $\mathrm{Rb} B k g$ & Cs Bkg \\
\hline 9 Aug 2006 & a & 4 & 2.00 & 514.40 & 0.016 & 0.006 \\
\hline 10 Aug 2006 & a & 4 & 1.09 & 1439.83 & 0.043 & 0.013 \\
\hline 11 Aug 2006 & a & 4 & 0.77 & 902.18 & 0.055 & 0.018 \\
\hline 14 Aug 2006 & a & 4 & 1.37 & 452.61 & 0.024 & 0.008 \\
\hline 15 Aug 2006 & a & 4 & 1.08 & 796.94 & 0.034 & 0.010 \\
\hline 16 Aug 2006 & a & 4 & 1.48 & 439.43 & 0.018 & 0.006 \\
\hline 17 Aug 2006 & a & 4 & 0.21 & 883.06 & 0.032 & 0.009 \\
\hline 18 Aug 2006 & a & 4 & 0.53 & 1400.18 & 0.083 & 0.017 \\
\hline 20 Aug 2006 & a & 4 & 0.68 & 772.84 & 0.024 & 0.005 \\
\hline 21 Aug 2006 & a & 4 & 0.90 & 368.04 & 0.011 & 0.003 \\
\hline 21 Aug 2006 & $\mathrm{c}$ & 5 & 167.29 & 1046.24 & 0.613 & 0.170 \\
\hline 22 Aug 2006 & c & 5 & 218.54 & 759.97 & 0.488 & 0.191 \\
\hline 23 Aug 2006 & c & 5 & 365.30 & 664.10 & 0.434 & 0.198 \\
\hline 4 Sep 2006 & d & 9 & 0.16 & 142.18 & 0.014 & 0.006 \\
\hline 5 Sep 2006 & d & 9 & 0.34 & 112.77 & 0.009 & 0.003 \\
\hline 6 Sep 2006 & d & 9 & 0.29 & 220.22 & 0.011 & 0.004 \\
\hline 7 Sep 2006 & d & 9 & 0.29 & 257.43 & 0.014 & 0.005 \\
\hline 8 Sep 2006 & d & 9 & 0.30 & 220.43 & 0.124 & 0.065 \\
\hline 12 Sep 2006 & d & 9 & 0.18 & 664.68 & 0.149 & 0.069 \\
\hline 13 Sep 2006 & $\mathrm{c}$ & 5 & 12.94 & 76.32 & 0.014 & 0.004 \\
\hline 14 Sep 2006 & c & 5 & 21.09 & 105.01 & 0.020 & 0.006 \\
\hline 15 Sep 2006 & c & 5 & 17.92 & 61.70 & 0.010 & 0.004 \\
\hline 18 Sep 2006 & $\mathrm{e}$ & 1 & 0.30 & 699.00 & 0.181 & 0.046 \\
\hline 18 Sep 2006 & e & 9 & 1.07 & 7.57 & 0.014 & 0.010 \\
\hline 18 Sep 2006 & c & 5 & 4.18 & 260.06 & 0.040 & 0.022 \\
\hline 19 Sep 2006 & d & 9 & 0.22 & 60.86 & 0.011 & 0.006 \\
\hline 21 Sep 2006 & d & 9 & 0.09 & 106.44 & 0.052 & 0.011 \\
\hline 22 Sep 2006 & d & 9 & 0.10 & 317.45 & 0.071 & 0.016 \\
\hline 26 Sep 2006 & $\mathrm{c}$ & 5 & 10.09 & 226.23 & 0.024 & 0.011 \\
\hline 27 Sep 2006 & $\mathrm{c}$ & 5 & 283.63 & 337.15 & 0.042 & 0.016 \\
\hline 28 Sep 2006 & c & 5 & 326.27 & 367.70 & 0.046 & 0.019 \\
\hline 29 Sep 2006 & $\mathrm{c}$ & 5 & 826.78 & 511.94 & 0.144 & 0.055 \\
\hline 29 Sep 2006 & e & 1 & 0.64 & 34.97 & 0.007 & 0.003 \\
\hline 29 Sep 2006 & d & 9 & 0.37 & 466.57 & 0.085 & 0.032 \\
\hline 10 Oct 2006 & d & 9 & 0.61 & 438.80 & 0.203 & 0.089 \\
\hline 10 Oct 2006 & $\mathrm{j}$ & 2 & 0.73 & 59.32 & 0.009 & 0.005 \\
\hline 11 Oct 2006 & $\mathrm{j}$ & 2 & 2.75 & 152.15 & 0.007 & 0.003 \\
\hline 12 Oct 2006 & $\mathrm{j}$ & 2 & 1.51 & 152.68 & 0.014 & 0.004 \\
\hline 17 Oct 2006 & $\mathrm{j}$ & 2 & 0.95 & 598.86 & 0.028 & 0.011 \\
\hline 18 Oct 2006 & $\mathrm{j}$ & 2 & 0.69 & 507.74 & 0.016 & 0.006 \\
\hline 19 Oct 2006 & $\mathrm{j}$ & 2 & 0.56 & 354.14 & 0.019 & 0.008 \\
\hline 20 Oct 2006 & $\mathrm{j}$ & 2 & 0.68 & 536.71 & 0.017 & 0.006 \\
\hline 23 Oct 2006 & $\mathrm{j}$ & 2 & 0.86 & 280.69 & 0.019 & 0.007 \\
\hline 24 Oct 2006 & $\mathrm{j}$ & 2 & 19.11 & 694.11 & 0.060 & 0.026 \\
\hline 25 Oct 2006 & $\mathrm{j}$ & 2 & 12.66 & 771.84 & 0.055 & 0.022 \\
\hline 27 Oct 2006 & $\mathrm{e}$ & 1 & 0.09 & 52.90 & 0.011 & 0.002 \\
\hline 31 Oct 2006 & $\mathrm{c}$ & 5 & 6.94 & 22.20 & 0.008 & 0.002 \\
\hline 1 Nov 2006 & $\mathrm{c}$ & 5 & 11.89 & 147.23 & 0.006 & 0.002 \\
\hline 2 Nov 2006 & c & 5 & 324.38 & 128.81 & 0.008 & 0.002 \\
\hline 3 Nov 2006 & $\mathrm{c}$ & 5 & 178.84 & 300.52 & 0.017 & 0.003 \\
\hline 7 Nov 2006 & $\mathrm{j}$ & 2 & 9.82 & 683.59 & 0.031 & 0.009 \\
\hline 8 Nov 2006 & $\mathrm{j}$ & 2 & 16.83 & 725.89 & 0.033 & 0.011 \\
\hline 9 Nov 2006 & $\mathrm{j}$ & 2 & 8.60 & 288.02 & 0.025 & 0.008 \\
\hline 10 Nov 2006 & c & 5 & 217.02 & 432.29 & 0.034 & 0.008 \\
\hline 13 Nov 2006 & $\mathrm{j}$ & 2 & 4.21 & 237.98 & 0.023 & 0.007 \\
\hline 13 Nov 2006 & $\mathrm{e}$ & 1 & 0.08 & 97.03 & 0.110 & 0.006 \\
\hline 14 Nov 2006 & $\mathrm{e}$ & 1 & 0.14 & 112.57 & 0.010 & 0.003 \\
\hline 15 Nov 2006 & $\mathrm{j}$ & 2 & 3.35 & 121.40 & 0.026 & 0.010 \\
\hline 16 Nov 2006 & $\mathrm{j}$ & 2 & 0.67 & 329.30 & 0.033 & 0.013 \\
\hline 17 Nov 2006 & d & 9 & 0.30 & 42.56 & 0.004 & 0.002 \\
\hline 20 Nov 2006 & $\mathrm{c}$ & 5 & 317.87 & 314.98 & 0.020 & 0.007 \\
\hline 22 Nov 2006 & c & 5 & 101.05 & 62.41 & 0.037 & 0.006 \\
\hline 24 Nov 2006 & c & 5 & 83.24 & 320.34 & 0.042 & 0.010 \\
\hline 27 Nov 2006 & $\mathrm{e}$ & 1 & 0.15 & 596.33 & 0.025 & 0.006 \\
\hline 29 Nov 2006 & $\mathrm{e}$ & 1 & 0.19 & 638.18 & 0.025 & 0.007 \\
\hline 30 Nov 2006 & c & 5 & 73.62 & 217.96 & 0.014 & 0.004 \\
\hline 1 Dec 2006 & $\mathrm{c}$ & 5 & 86.85 & 413.92 & 0.027 & 0.007 \\
\hline 2 Dec 2006 & e & 1 & 0.22 & 598.30 & 0.057 & 0.009 \\
\hline 4 Dec 2006 & $\mathrm{e}$ & 1 & 0.19 & 634.70 & 0.045 & 0.009 \\
\hline 5 Dec 2006 & $\mathrm{c}$ & 5 & 155.70 & 563.94 & 0.034 & 0.010 \\
\hline 6 Dec 2006 & $\mathrm{e}$ & 1 & 0.33 & 741.09 & 0.036 & 0.008 \\
\hline 7 Dec 2006 & $\mathrm{e}$ & 1 & 0.30 & 724.49 & 0.035 & 0.009 \\
\hline 8 Dec 2006 & e & 1 & 0.16 & 524.38 & 0.024 & 0.006 \\
\hline 11 Dec 2006 & $\mathrm{e}$ & 1 & 0.80 & 596.19 & 0.062 & 0.023 \\
\hline 12 Dec 2006 & $\mathrm{e}$ & 1 & 0.77 & 559.75 & 0.068 & 0.026 \\
\hline 13 Dec 2006 & $\mathrm{e}$ & 1 & 0.39 & 605.62 & 0.075 & 0.031 \\
\hline 14 Dec 2006 & $\mathrm{e}$ & 1 & 0.51 & 659.52 & 0.085 & 0.037 \\
\hline 15 Dec 2006 & $\mathrm{e}$ & 1 & 0.40 & 889.42 & 0.089 & 0.040 \\
\hline 19 Dec 2006 & $\mathrm{e}$ & 1 & 0.33 & 712.80 & 0.068 & 0.027 \\
\hline
\end{tabular}


Rather, it reduces the build-up of unwanted alkali elements in parts of the instrument where secondary ionisation can reintroduce them into subsequent samples as contamination. As this is only a change to the instrument set-up procedure, it does not require a change to the protocols used by analysts. The lower backgrounds that result from this study have enabled the determination of the alkali content of olivine (Mallmann et al., 2009), feldspar lamellae (Parsons et al., 2009), ultramafic melt inclusions (Kallio and Ireland, 2006), and Martian meteorites (Stopar et al., 2007). Although only a dozen glass beads were cast, limited supplies are available from the authors on request.

Acknowledgements. This project was not funded by any grant or scholarship, but was performed by technical staff as part of our brief to improve instrumental performance. We thank Hugh O'Neill and Stephen Eggins for giving us the latitude to look into this issue, Mike Shelley for instruction on excimer laser and ICP-MS maintenance, and Carl Spandler and two anonymous reviewers for thoughtful reviews of the manuscript.

Edited by: W. Schmidt

\section{References}

Eggins, S. M.: Laser Ablation ICP-MS Analysis of Geological Materials Prepared as Lithium Borate Glasses, Geostand. Geoanal. Res., 27, 147-162, 2003.

Eggins, S. M., and Shelley, J. M. G.: Compositional Hetergeneity in NIST SRM 610-617 Glasses, Geostand, Geoanal, Res,, 26, 269286, 2002.

Eggins, S. M., Woodhead, J. D., Kinsley, L. P. J., Mortimer, G. E., Sylvester, P., McCulloch, M. T., Hergt, J. M., and Handler, M. R.: A simple method for the precise determination of $>=40$ trace elements in geological samples by ICPMS using enriched isotope internal standardization, Chem. Geol., 134, 311-326, 1997.

Eggins, S., Grün, R., Pike, A., Shelley, M., and Taylor, L.: ${ }^{238} \mathrm{U}$, ${ }^{232} \mathrm{Th}$ profiling and U-series isotope analysis of fossil teeth by laser ablation-ICPMS, Quaternary Sci. Rev., 22, 1373-1382, 2003.

Gao, S., Liu, X., Yuan, H., Hattendorf, B., Günther, D., Chen, L., and Hu, S.: Determination of Forty Two Major and Trace Elements in USGS and NIST SRM Glasses by Laser Ablation-Inductively Coupled Plasma-Mass Spectrometry, Geostand. Newsletter, 26, 181-196, 2002.

Govindaraju, K.: Compilation of working values and sample description for 383 geostandards, Geostand. Newsletter, 18, 1-158, 1994.
Hamilton, D. L. and Henderson, D. M. B.: The preparation of silicate compositions by a gelling method, Mineral. Magazine, 36, 832-838, 1968.

Hinton, R. W.: NIST SRM 610,611 and SRM 612, 613 multielement glasses: Constraints from element abundance ratios measured by microprobe techniques, Geostand. Newsletter, 23, 197207, 1999.

Kallio, A. and Ireland, T.: Silicate melt inclusions in komatiites as potential indicators for crustal growth, Geochim. Cosmochim. Acta, 70, p. A301, 2006.

Longerich, H. P., Jackson, S. E., and Gunther, D.: Laser Ablation Inductively Coupled Plasma Mass Spectrometric Transient Signal Data Acquisition and Analyte Concentration Calculation, J. Anal. Atomic Spectrom., 11, 899-904, 1996.

Longhi, J.: Liquidus equilibria and solid solution in the system $\mathrm{CaAl}_{2} \mathrm{Si}_{2} \mathrm{O}_{8}-\mathrm{Mg}_{2} \mathrm{SiO}_{4}-\mathrm{CaSiO}_{3}-\mathrm{SiO}_{2}$ at low pressure, Am. J. Sci., 287, 265-331, 1987.

Mallmann, G., O’Neill, H. S. C., and Klemme, S.: Heterogeneous distribution of phosphorus in olivine from otherwise wellequilibrated spinel peridotite xenoliths and its implications for the mantle geochemistry of lithium: Contributions to Mineralogy and Petrology, Vol. 158, 485-504, 2009.

Norman, M. D., Griffin, W. L, Pearson, N. J., Garcia, M. O., and O'Reilly, S. Y.: Quantitative analysis of trace element abundances in glasses and minerals: a comparison of laser ablation inductively coupled plasma mass spectrometry, solution inductively coupled plasma mass spectrometry, proton microprobe and electron microprobe data, J. Anal. Atomic Spectrom., 13, 477482, 1998.

Parsons, I., Magee, C. W., Allen, C. M., Shelley, J. M. G., and Lee, M. R.: Mutual replacement reactions in alkali feldspars II: trace element partitioning and geothermometry: Contributions to Mineralogy and Petrology, Vol. 157, 663-687, 2009.

Pearce, N. J. G., Perkins, W. T., Westgate, J. A., Gorton, M. P., Jackson, S. E., Neal, C. R., and Chenery, S. P.: A compilation of new and published major and trace element data for NIST SRM 610 and NIST SRM 612 glass reference materials, Geostand. Newsletter, 21, 115-144, 1997.

Stopar, J. D., Taylor, G. J., and Norman, M. D.: Aqueous alteration in Naklite MIL 03346: LA-ICPMS and Raman spectrometry, 7th International Mars Conference, Pasadena CA, USA, 2007.

Sun, S-S. and McDonough, W. F.: Chemical and isotopic systematics of oceanic basalts: implications for mantle composition and processes Geological Society, London, Special Publications, Vol. 42, 313-345, 1989.

Tye, C., and Sakata, K.: The new soft extraction mode, ICP-MS J., 8, p. 7, 2000 . 